\title{
The Way Ahead: Future Challenges for Genealogy
}

As a record of the Conference proceedings, we are publishing the original submitted abstracts of the papers and posters to be presented at the Register of Qualified Genealogists' first conference held on 20 October 2018 at the National Railway Museum in York, England. All speakers were invited to submit their papers for publication in the journal, and we hope to publish several of them in due course.

\section{Keynotes}

\section{Challenging assumptions about marriage law and practice} Rebecca Probert

What options were available to couples marrying in the nineteenth century and what inferences can we draw from their choice of ceremony, whether religious or civil? How long did Victorian marriages actually last? How did couples describe themselves when remarrying, whether legally or illegally, and are there any factors that should alert us to look beyond the face of the register? And what happened to those who had remarried illegally when they were found out? In this talk, Professor Rebecca Probert will challenge some assumptions about how Victorian couples engaged with the law, and draw on new evidence to help put genealogists' findings in context.

Rebecca Probert, professor of law at Exeter University, has written on all aspects of family law and is the author of many scholarly articles, books and monographs. Her main research interests include marriage, cohabitation, bigamy and divorce, with key works including Marriage Law and Practice in the Long Eighteenth Century: A Reassessment (CUP, 2009), The Changing Legal Regulation of Cohabitation: From Fornicators to Family, 1600-2010 (CUP, 2012) and Marriage Law for Genealogists (Takeaway, 2012).

\section{Family historians and historians of the family: the value of collaboration} Laura King

What new knowledge can be created if we bring together historians with different communities of researchers to discuss their work and experiences with history? Whilst historians of the family and family historians are not two distinct and separate groups, there is a huge potential in bringing together those researching their own family histories with social and public historians examining families' lives in the modern period to produce history in diverse forms. Through my current Arts and Humanities Council-funded project, 'Living with Dying', I am working with a group of fifteen family historians. By offering training, the chance to discuss progress and challenges in their research, and a social element to our work, the family historians have found this useful. By working with social historians (myself and Jessica Hammett), they are also learning more about the historical context in which their families lived. In turn, we are interviewing each member of the group about their memories and what they know about their relatives, to gain a detailed picture of their families in the period 1900-50. We also (with their consent) access documents and materials from each historian's 'family archive', and learn about their family's history through their writing and documentation of their research. Does this privileged access into 'ordinary' families' histories offer a new way for social historians to access a history from below perspective?

Dr Laura King is Associate Professor in modern British history at the University of Leeds. She researches families, emotional relationships and everyday life in modern Britain. Her current project focuses on death, dying and how we remember the dead, and is entitled 'Living with Dying: Everyday Cultures of Dying within Family Life in Britain, c.1900-50s'. Part of the research involves considering the way this innovative collaborative methodology might be used in other contexts and projects, and how collaboration might be beneficial for a wide range of family and academic historians.

\section{Genetic genealogy: using DNA in family history and beyond} lain McDonald

DNA testing is a powerful tool in the genealogist's handbook, from opening up new avenues to proving questionable relationships. The field is now maturing and, in this talk, I will review its current state, and what we can expect from it over the next few years. This will cover both what we can learn from recent genealogy and what we can learn about our ancient past, including examples of how to get the most out of your test results. 
Dr lain McDonald is an astrophysicist working at the University of Manchester and Honorary Research Fellow to the Genealogical Studies Programme at the University of Strathclyde. He has been using physical, statistical and mathematical techniques to develop tools for both conventional and genetic genealogy. His speciality is in estimating the dates of male-line (surname) relationships from commercial genetic tests and using these to construct models of population movements between mainland Europe and the British Isles over the last 5000 years.

\title{
Conference papers
}

\author{
Metadata magic and data standards for using digital images in genealogical research \\ Sue Adams
}

Digital images have become ubiquitous in genealogy, yet commonly used software inconsistently handles and incorporates digital images in genealogical research. Digital images serve as copies of documents and traditional photographs. Metadata is information about the digital image and what it depicts. Citation elements and index terms are examples of metadata frequently used by genealogists. Metadata can be read and used by computers enabling a variety of useful functions. Data standards are like toothpaste in that everyone has their favourite flavour. Widely adopted standards are necessary for tools to work well and preserve data integrity across applications. I briefly survey the use of genealogical, digital image and archival data standards in a selection of popular genealogy applications. GEDCOM is still the de facto genealogical data standard. The Metadata Working Group has published guidelines for handling image metadata. The General International Standard Archival Description (ISAD(G)) is an internationally recognised archival standard. I propose a pragmatic tagging system for inclusion into digital image metadata and advocate for improved compliance and integration of data standards.

Sue Adams contributes to genealogical knowledge by blogging at Family Folklore and Worldwide Genealogy, developing data standards through the work of FHISO, participating in online discussions and speaking at conferences and fairs. Since gaining an MSc in 2012, Sue has undertaken research commissions on families in England, Scotland and Canada. She has served on the 'Ask the Experts' panel at Who Do You Think You Are? LIVE! from 2014 and tutored at Clans and Surnames in 2017. In 2018, she will present a half-day course for the Society of Genealogists, 'Maps and property records for family historians', and speak at 'Secret Lives'. Sue's research interests include English land records, migration, digital technologies and genealogical data standards.

\section{‘Place of origin' in the genealogical records of Manx-US immigrants}

Jane Barton

Genealogists searching for documents relating to Manx-US immigrants frequently encounter a problem - the 'place of origin' of Manx individuals is often given as England, particularly in search results and indexes, despite the Isle of Man being politically and administratively distinct from England within the British Isles. Why is this? Did Manx immigrants choose to describe themselves as English? Did US officials understand the peculiar situation of the Isle of Man? Were data-recording and indexing systems unable to accommodate this peculiarity? This study attempts to establish whether the inconsistencies in 'place of origin' data relating to Manx-US immigrants are due to structural constraints and artefacts of the data model, the cultural context of the Manx immigrant community, data quality issues or some combination thereof. Using a sample of twelve Manx individuals who migrated to the US before 1914, the study will investigate how 'place of origin' was recorded in the documents associated with each individual and how this data was subsequently indexed in finding aids and databases; explore the historical and cultural context in which primary source documents were created; and evaluate the quality of primary and secondary data on 'place of origin'. The methodology draws on a range of metadata modelling, quality assessment and quality assurance techniques developed in the digital libraries and archives sectors. Preliminary findings suggest that Manx immigrants are recorded as being of Manx origin on a majority of documents but, due to a complex mix of structural, cultural and quality issues, this is not always apparent in indexes and search results. Specific results will be of immediate benefit to those researching Manx-US immigrants but the findings will also be highly relevant to anyone interested in deepening their understanding of how large genealogical databases are constructed and how to search them more effectively.

Jane Barton is a student member of RQG. She is a student at the University of Strathclyde and has just completed her postgraduate diploma.

\section{The archival future}

Caroline Brown

This paper will consider the archival landscape of the future and the impact that this will have on genealogical research. The last twenty years or so have seen huge changes in the way genealogical research is carried out. Digitisation and the online environment have seen archival 
sources becoming more easily available to an increasing number of people. This opening up of access has brought opportunities but has also not been without its issues and this paper will begin by examining some of these. It is not just digitisation that has the potential to transform research. Today's information is created and recorded digitally; the archival sources of the future will not be on parchment or paper but produced and stored as digital files. This has implications for the types of sources that are created, what are kept in the long term and how these will be accessed. This is a world of social media, big data, fake news, the right to be forgotten, redaction and reuse. What impact will this have on people wishing to research their family history in the future? The paper will look at these issues from the perspective of the archivist. Traditionally seen as the guardians of evidence of the past, archivists are having to re-examine their roles and to defend their relevance in a digital world.

Caroline Brown is University Archivist at the University of Dundee where she manages the archives, rare books and museum and art collections. She is also Programme Leader on the distance learning archive and family history courses which are offered online through the Centre for Archive and Information Studies at the university.

\section{Researching nineteenth-century insanity}

John Burt and Kathryn Burtinshaw

This presentation looks at nineteenth-century asylums and examines the records that are available to assist in researching 'lunatic ancestors'. Our study includes individuals defined as criminal lunatics who were incarcerated at His/Her Majesty's pleasure. A brief explanation of the development and expansion of the asylum system and evolving methods of treatment using 'moral' rather than the abusive and punitive treatment of patients will be given. The introduction of specialist facilities to house the criminally insane, such as Broadmoor Hospital in England and the Criminal Lunatic Department of the General Prison of Perth in Scotland, will be explored using case studies from contemporary records. Medical case notes are a valuable primary source much underused by researchers. Furthermore, patients requiring medical intervention shared thoughts and feelings about their conditions with the doctors and staff attending them and often disclosed private information about family relationships. Patient testimonies and their correspondence with the outside world are unique ways of discovering and identifying more about individuals and families. This lecture will focus on nineteenth-century asylum and prison records and aims to show that patients deemed to be insane continued to have a voice despite being locked away from the rest of society. We hope to end the lecture with a question on ethics. As researchers, how should we go about protecting not only the feelings of others but also our own reputations. Is it ethical to publish information that is in the public domain simply because it makes a good story?

Dr John Burt, MB, Ch.B., BA, Cert. Archaeol., Dip.F.S.H., MSc, F.S.A.Scot., QG, is a retired general medical practitioner and a qualified genealogist. He worked in the NHS for over thirty years and has a wealth of experience in medical matters. During that time he gained a postgraduate certificate in archaeology from the University of Edinburgh and a master's degree from the University of Strathclyde. His interest in mental health has led to two publications: Lunatics, Imbeciles and Idiots (ISBN 9781473879034) in 2017 and Madness, Murder and Mayhem (ISBN 9781526734556) in 2018.

Kathryn Burtinshaw, MSc, QG, is a professional genealogist and family historian. With careers in both the Diplomatic Service and the Security Service she is an experienced researcher who has completed an advanced diploma in English local history with the University of Oxford. Kathryn completed her MSc degrees in genealogy, palaeography and heraldry with the University of Strathclyde. John and Katheryn's shared interest in mental health has led to two books published by Pen \& Sword History: Lunatics, Imbeciles and Idiots: A History of Insanity in Nineteenth Century Britain and Ireland (2017) and Madness, Murder and Mayhem: Criminal Insanity in Victorian and Edwardian Britain (2018). Kathryn and John run a genealogy company, Pinpoint Ancestry, with bases in Wales and Scotland.

\section{Tracing Huguenots in the seventeenth and eighteenth centuries in French local archives} Lucie Drouin

My project for the postgraduate diploma is based on primary sources related to Protestants between 1598 (Edict of Nantes) and 1792 (creation of the civil records), held by the French Archives Départementales. This study focuses on the department of La Sarthe. It aims to assess the value of these resources to genealogists and the likelihood of locally ascertaining Huguenot lineage. Several case studies also help in assessing the benefit of each primary source examined. The four surviving Protestant parish registers created in La Sarthe after the Edict of Nantes have been investigated. This has highlighted the importance of the local historical context for the local Reformed Churches and the registration of vital events. The study also shows the significance of the social composition of the Church members (gentry, craftsmen, etc.) to conduct the research beyond the seventeenth century through armorials, charters and guild records. The period of clandestineness for Huguenots after the Edict of Fontainebleau officially banished Calvinism from France (1685) has been scrutinized through two different resources: firstly, the 
abjurations from Protestantism registered in the Catholic parish records in 1685-1686; then the Protestant burial registers held by bailiffs, sole legal vital records related to Huguenots in the eighteenth century. These investigations show to what extent these archives may be used as substitutes for missing vital records. Genealogical research related to Huguenot or Catholic ancestry in France cannot be planned in the same way. Knowing the specificities of Protestant records enables one to understand where to pinpoint the right register and what genealogical information may be expected when tracing Huguenots in French local archives prior to 1792.

Lucie Drouin is an RQG student member who lives and works in France. She is a student at the University of Strathclyde and has just completed her postgraduate diploma.

\section{How do clients choose a genealogist and how can we best promote our services? \\ Linda Hammond}

What do clients value in a genealogist? Where do genealogists find clients? What do they expect from each other, and do their expectations match? To find out the answers, I carried out two surveys in 2017. One survey collected the views of 100 genealogists around the world, and the other surveyed 100 prospective clients. Surveying genealogists and prospective clients from around the globe, by way of an online survey utilising mainly multiple-choice questions, I analysed a number of areas. I looked at how clients sought a genealogist and how genealogists advertised their services. I examined rates of pay and communication preferences. The work experience of a genealogist and their qualifications was another factor examined in the survey. The set-up of a genealogist's business and whether they were a member of a professional body were also considered to see their influence on a client's choice. Outside of the multiple-choice questions I also investigated what a client looks for when choosing a genealogist to work with and what would persuade them to use one genealogist over another. The outcome of the survey was to show genealogists how to better connect with prospective clients. It proved to give some interesting results and enabled us to enter into the thought processes of future clients when seeking a genealogist to work with. By knowing what prospective clients are looking for and the things they value in a genealogist you can analyse your situation and make simple changes to promote your services and gain more clients.

Linda Hammond is a qualified genealogist with over thirty years' experience. She lives in south-west France and carries out research for clients worldwide (www.lindahammondresearch.com). She completed her master's degree with the University of Strathclyde in 2016 where her research specialism was reformatory and industrial schools. This work has been extended to a website (www.DERIS.org) which aims to digitize and index the complete archives for Devon \& Exeter boys' reformatory and industrial schools, making them freely accessible online.

\section{Breaking down brick walls: using DNA data to solve family history mysteries \\ Laura House}

It is every genealogist's worst nightmare: we work hard on our family trees and build a fascinating historical narrative, and then our progress is unexpectedly hindered by an illegitimacy, an adoption, or a well-concealed name change. The paper trail disappears, and all that remains is an unsightly gap in the pedigree chart - a constant reminder of a story which may never be told. The research discussed in this paper is part of a project to devise simple and clear strategies for the genealogist, which will enable them to solve these family history mysteries using direct-toconsumer genetic testing as a substitute for missing or non-existent paper documents. This ongoing project examines several individual cases in which participants have a surname change in their genealogy which cannot be explored using traditional genealogical research. The participants contribute their $Y$ and autosomal DNA data, and these are then used to investigate the surname change. Although one can rarely claim to have absolute proof when using DNA data to solve a historical mystery, in several cases the evidence leads to a probable solution. Likely fathers of illegitimate ancestors are identified, and ancestors who changed their surnames are connected to their original family name. These examples will be discussed during the presentation, and the newly developed methodologies will be shared with the audience. The value and the limitations of these methodologies will be explored, and the audience will leave with a better understanding of how genetic genealogy can benefit their research. Feedback on these methodologies is very welcome. The goal of this research is to make genetic genealogy accessible to all, and to ensure that DNA data is someday a commonplace tool used by the genealogist to confirm, amend and expand their family tree.

Laura House is a professional genetic genealogist, teacher and private tutor. She has a postgraduate diploma in genealogical, palaeographic and heraldic studies and is currently working towards an MSc at the University of Strathclyde. Her research focuses on the use of DNA (Y and autosomal) in the investigation of illegitimacies, adoptions and surname changes. Laura teaches genealogy courses in London and Gloucestershire, and recently worked behind the scenes on ITV's 'Coronation Street's DNA Secrets'. She is currently working as a researcher on a book about the history of the FDA (First Division Association) which is being published next year to commemorate their centenary. 
How can the archives of the International Tracing Service (ITS) help in researching the family history of Nazi Holocaust victims?

Des Maguire

The ITS is a facility, originally established by the Red Cross in London in 1943, to assist individuals in tracing relatives who were displaced in Europe. After the war, it was located in Bad Arolsen, West Germany. Its main roles, formalised in the Bonn Accords of 1955, were to trace missing persons and to collect, classify and preserve relevant documents. To date, it has accumulated 50 million pages of documents covering World War II and the post-war period. These documents contain names, dates, places and relationships which are a boon to family historians working in this area. A good example is Babette Nordheim. Her name first appeared on a Gestapo list from 1942 deporting Jews from Dresden to the Theresienstadt concentration camp. Subsequent research in the ITS archives and in other sources revealed further details about her and her family which uncovered the tragic fate of three generations of her family at the hands of the Nazis. Above all, these details show the reality of the Nazi racial policies as they impacted upon the lives of individual Jews. This paper will give a brief introduction to anyone interested in undertaking family history research involving victims of the Holocaust.

Des has just completed and passed his MSc at the University of Strathclyde. Des is a volunteer translator German/English for the Wiener Library in London and is currently translating Holocaust eye-witness statements. He also undertakes some genealogy and research assignments for the Commission for Looted Art from time to time.

\section{Americans resident in Scotland, 1850-1901: the pleasures and pains of preparing a PhD project} Tahitia McCabe

At a time when most people were emigrating the other way, there was a small population of Americans resident in Scotland. The author has spent the previous year getting ready to start a $\mathrm{PhD}$ and this talk will outline the preparation required and the research undertaken to date. The project is planned to be a demographic and genealogical survey of this group, exploring community links and inter-relatedness.

Tahitia McCabe was a librarian at the Alaska State Library and is currently the course director for the University of Strathclyde's Genealogical, Palaeographic and Heraldic Studies Postgraduate Programme. She is also the lead educator on the 'Genealogy: Researching Your Family Tree' massive online open course offered through FutureLearn.

\section{Genealogists, volunteers and big data challenges: the 'Railway Work, Life \& Death' Project}

Mike Esbester and Peter Thorpe

If you're researching nineteenth- or twentieth-century genealogy, amongst the many challenges you face is the sheer quantity of data that exists and which might be useful. How do you know what is out there, and how do you access it? How do archives disseminate information about their holdings and facilitate access? The advent of the internet and digital resources has revolutionised practice to a point, but plenty of sources remain little known, difficult to access, and underutilised. Cross-institution collaboration, crowdsourcing and projects involving volunteers are parts of the solution to these challenges, albeit ones which require careful handling. This presentation explores some of the issues this raises and introduces a new, free resource for genealogists from the 'Railway Work, Life \& Death' Project: a database of early twentieth-century British and Irish railway worker accidents. The project is a collaboration between the National Railway Museum (NRM) and the University of Portsmouth. Using a proto-crowdsourcing methodology, NRM volunteers have documented in extraordinary detail nearly 4,000 accidents between 1911 and 1915, making all the data (tens of thousands of datapoints) freely available from our project website. In the talk we focus on the methodological and collaborative aspects, highlighting the potential for genealogical research across many topics. We will demonstrate the value of this specific resource for genealogists, as well as the advantages to all of working with multiple stakeholders (including, here, the current rail industry, rail enthusiasts, museums professionals, archivists and academics). Overall, the presentation will examine the challenges and opportunities of making large quantities of data available. As we develop our project into the inter-war period we are keen to work with genealogists to ensure it continues to meet your needs. We welcome insights from conference delegates, and this is a great opportunity for you to influence our project as it grows.

Dr Mike Esbester is Senior Lecturer in history at the University of Portsmouth. His research focuses on the history of safety, risk and accident prevention in twentieth-century Britain, with a particular interest in the railway industry. Mike is the academic lead on the 'Railway Work, Life \& Death' Project (www.railwayaccidents.port.ac.uk; @RWLDproject).. 
Peter Thorpe has worked in Search Engine, the National Railway Museum's Library and Archive centre, for over ten years. He has recently completed a secondment managing the public service and curating the museum's library collections as well as being NRM's lead on the 'Railway Work, Life \& Death' Project. Peter currently works within the team that provides the front-of-house service in Search Engine as well as providing support for the museum's many cataloguing projects.

\section{The family tree of Scottish Jewry}

Michael Tobias

This presentation will deal with the International Institute for Jewish Genealogy sponsored project '200 Years of Scottish Jewry - a Genealogical and Demographic Survey'. As originally conceived, the endeavour began as an attempt to construct a 'family tree' of a national Jewry, something that had never been attempted before. The Jewish community in Scotland, which emerged two centuries ago with the founding of a Hebrew congregation in Edinburgh in 1817, was chosen for this purpose. Very rapidly, it became clear that for the experiment to proceed a comprehensive demographic survey of the Jews in Scotland was called for. As work progressed, it became apparent that a broad reconstruction of the Jewish community in Scotland was within reach, based on the wealth of new data being gathered, mainly from online sources. That new knowledge provided fresh insights into Scottish Jewry and challenged a number of long-standing assumptions about its origins and evolution. The procedures employed to identify and gather the available data included automated scripted searches of online resources. The methods adopted will be briefly described, as will the analysis and mapping of the origins of the Jewish immigrants to Scotland and their settlement patterns and development over time. An overview will be given of the process of linking all of the data gathered into one large collection of linked family trees, an effort complicated by the multiple spellings of East European names and a tendency among immigrant Jews to have frequent name changes as they transited from their countries of origin into Scottish life.

Michael Tobias has a BSc Honours in mathematics and physics and qualified as a Fellow of the Faculty of Actuaries. In 2012 he completed a master's degree in genealogical, palaeographic and heraldic studies at Strathclyde University. He is a co-founder of Jewish Records Indexing Poland and Vice President, Programming of JewishGen, Inc. He was database matching consultant to the International Commission on Holocaust Era Insurance Claims (ICHEIC). He has contributed to various journals, radio and TV programmes including 'Who Do You Think You Are?' both in the UK and USA. He has spoken at many conferences including the International Association of Jewish Genealogical Societies (IAJGS) annual conference since 1996 and was awarded their Lifetime Achievement award in Washington, DC in 2011.

\section{The way ahead: future challenges for genealogy}

Penny Walters

What constitutes a 'family' now? Traditional families with two married heterosexual parents and children are being replaced by fewer marriages, fewer children, fewer women changing their surname, same-sex marriages, and step-families. People are already shocked that only a couple of generations ago, their ancestors had fifteen children. The terms used within 'family' have specific roles, responsibilities, duties; we can list what a 'mother' should do. What has been the impact of religion, philosophy, psychology, and culture on family history? We include and exclude people from our lives, as well as our trees. Families can be fragmented (through disputes, adoption, fostering, war, famine, enslavement, diaspora). Researching and devising a family tree traditionally involved asking relatives about their lives and undertaking a paper trail. However, it now involves finding previously inaccessible records and dealing with strangers via the internet, people that you will probably never meet. You can put your tree on websites, and strangers can glean information from it and add your photos. DNA testing has revolutionised genealogy. Results include ethnicity heritage estimates but can ethnicity be measured? Known ethnicities can be confirmed, but also hidden ethnicities revealed. Positives to this can include visiting where ancestors came from, but often against a backdrop of diaspora, poverty or enslavement; are we at risk of cultural appropriation and romanticisation of homelands? DNA sites give us matches to fourth cousins; are they really a relative to have a relationship with? We can fill in some blanks or break brick walls by adding them to our tree, but why are we trying to 'find' people? What is our relationship to primates? Can we put pets and best friends on our tree? What about deleting relatives we don't like and haven't seen for years, or step-families? How will people access our social media accounts to devise a narrative about us? Should we leave our Facebook and Instagram passwords in our will? There won't be so many boxes of photographs under beds, but future generations will need access to our mobiles. So, what does the future hold? Should we be planning the future, including arranged marriages, deciding who our children can marry rather than recording the past in a retrospective tree? How should we record, for example, sperm donors (are they a 'father'?), or transgender people on our tree? Within genealogy, many new scenarios and ethical dilemmas are therefore arising. Can we professionalise genealogy from family history? People can now study accredited courses and join professional bodies which have regulations, codes of conduct, responsibilities, accountability and continuing professional development. 
Dr Penny Walters has been a university lecturer for over thirty years, teaching undergraduate and master's psychology and business studies throughout the UK. Penny's PhD (2001) investigated 'Ethical dilemmas in health promotion'. Penny was adopted at birth, and her ancestral search has taken her back from the UK, through south Wales' coalmines, to the Irish Famine, specifically to counties Cork and Kerry in southern Ireland. Penny completed the postgraduate certificate in genealogy from Strathclyde University, and is the editor of the journal of the Bristol \& Avon Family History Society. Penny lectures and writes articles about various genealogical topics: diaspora; Irish heritage; adoption; ethical dilemmas within genealogy; the psychology of searching; mixing DNA results with a paper trail; Ivory Coast ancestors (slave history); the professionalisation of genealogy; census taking in Egypt.

\section{Continuing professional development \\ Patricia Whatley}

Is learning ever completed? Almost everyone attending this conference will be 'qualified' by virtue of having undertaken educational courses provided either by the University of Strathclyde, the Institute for Heraldic and Genealogical Studies or the Centre for Archives and Information Studies, and will have client-based experience. As with any profession it is important to keep abreast of new developments and to learn, maintain and update skills. The RQG has taken steps to implement a system for its members to evidence their CPD activities in addition to providing opportunities via member meetings to discuss journal articles. The challenge for any professional is both to identify their own training needs and address those needs. The professional courses in family and local history offered by the Centre for Archive and Information Studies at the University of Dundee, delivered by distance learning, are one such method as the modules can be studied as CPD modules. Equally those organisations which do provide formal accredited courses need to ensure that these courses continue to meet the needs of potential students. This presentation will provide information on the content, mode of delivery and benefits of study at a distance and the possibilities for professional development, including the potential for $\mathrm{PhD}$ study. It looks at some of the current plans for further development and provides an opportunity for delegates to make suggestions.

Patricia Whatley is Senior Lecturer in history and archival studies and Director of the Centre for Archive \& Information Studies (www.dundee.ac. uk/cais) at the University of Dundee. She is a registered archivist with a PhD in history. She teaches in Scottish history and is responsible for master's dissertations and PhD applications. She is currently Chair of the Economic \& Social History Society of Scotland, a trustee of the Scottish Historical Trust and a member of the Council of the Scottish Society of the History of Medicine.

\section{Data mining to extract more information from digitised record sets}

Adam Winstanley

There has been a wealth of online digitised data made available in recent years, with many complete sets of records available. These include census, civil registration, church and other records. This has made searching much easier and accelerated the process of family history research while complying with genealogical proof standards. Where data includes many attributes (age, birthplace, relationships), the process of record linkage can be carried out to prove identification of individuals. There are many record sets, however, that have few if any attributes linked to individuals. These include lists of names on petitions and published donor lists to charities. It can be difficult to identify individuals in them and link them to other records. However, the association between names on the list can help (for example, if it comes from a particular town or parish, the pattern of names will be similar to other lists from that place). Data mining tools can be used to allow one to make possible identifications of individuals on such lists of names by linking them to more fully attributed data through analysis of the patterns of names present. Results can be displayed graphically and estimates made of the statistical probability of correct matches. The tools can be parameterised to take into account name variants in three specific ways: matching on strings, Soundex codes and indexing from a reference table. Testing of the data mining algorithms can be carried out by using examples with known provenance. Example results are displayed for some Irish case studies including the Morpeth Roll petition (1841) containing almost 160,000 names.

Adam Winstanley has academic qualifications in computer science, archaeology and genealogy from Cambridge, Queen's Belfast and Strathclyde universities. He worked as an archaeologist and cartographer with Ordnance Survey Northern Ireland for several years. He was a lecturer at Queen's University before taking up a post at Maynooth University in 1995, where he is currently a professor and heads the computer science department. He teaches and researches into systems for data analysis, particularly using spatial and historical data sets. His interests include Irish genealogical problem solving and the use of census substitutes. 


\section{Posters}

The Bawdy Court in Nottinghamshire between 1603 and 1643. Using English Ecclesiastical Court records to develop family stories

Carol Bannister

The overall aim of this poster is to demonstrate what the English Archdeaconry and Ecclesiastical Court records can tell us about the lives of the people between 1603 and 1643 . These records are usually available for each county in England. The data was compiled as part of the author's MSc dissertation at the University of Strathclyde and examined Catholic and Protestant religious dissenters living in Nottinghamshire during the reigns of James I of England and Charles I. The primary source records consisted of the Archdeaconry collection held by the University of Nottingham supplemented by the Nottinghamshire quarter sessions minute books held by Nottinghamshire Archives. The primary source data was analysed to develop a narrative with the intention of building a family story over the defined timeline. The Corrections Court compiled and recorded detailed cases of religious dissent, non-payment of church dues, sexual misconduct, clandestine marriages, disorderly behaviour in church precincts, and superstitious practices. Outcomes of the cases included dismissal of the case, compurgation (the accused could bring witnesses to purge themselves of the case leading to dismissal of the case), certification (where the accused could make good followed by the case being dropped), and penance or excommunication. This poster follows a family case study through the courts and shows how these records can be used to construct a family story useful for your client studies.

Street Arabs, vagrants and beggars: young criminals of the reformatory and industrial schools

Linda Hammond

By the end of the nineteenth century in Great Britain, one in every 230 children aged between five and fifteen had been incarcerated in either an industrial or reformatory school. Children entered these schools not just because they had been convicted of an offence; often poverty and lack of parental care were the sole reasons. Their time at these schools means they left behind a wealth of information for us to discover. Your ancestor may have led a very different life to what you thought and you may have no idea they ever attended one of these schools. Imagine finding a set of documents which gave you many years of in-depth detail on your ancestor, including anything from their physical description and family background to addresses and occupations of family members, and possibly even photographs and newspaper cuttings of their life events. Many reformatory and industrial schools have excellent records with an often impressive survival rate. The records typically contain family and personal information for poorer families which may not be found in any other contemporaneous records. The assessment of the potential genealogical value of these underused school records was a primary aim of my research. A quantitative approach exploring the admission and discharge registers of two schools showed the type of children who were committed to these different school systems and how they fared in life whilst at the schools and after their discharge. The schools' records proved to be of exceptional value to genealogists. The extensive information covering such a long time-span, ranging from family and life circumstances prior to admission to details on the boys' careers up to and sometimes beyond the three years after discharge, is invaluable to researchers.

\section{Charles Maitland, mystery man}

Sylvia Valentine

Edward Jenner is far better known for his discovery of cow pox to protect against smallpox than Charles Maitland. Yet Maitland was the first person to perform an inoculation in England, having learned about the procedure in Turkey where he was surgeon to the British ambassador to Turkey. The ambassador's wife, Lady Mary Wortley Montagu, had Maitland inoculate her daughter in London in 1722 and Maitland was present when the daughters of the future King George II were inoculated by the royal surgeon. He was involved in experiments when he inoculated condemned prisoners in Newgate Prison which some describe as the first clinical trials. He also attracted much criticism from some members of both religious and medical communities for defying the will of God. Little is known of his early career, and the genealogical information is sparse. According to the Fasti Academiae Mariscallanae of Aberdeen University produced in the late nineteenth century, he was a student at Aberdeen. However, if he had obtained a medical degree he would surely have styled himself 'Doctor', so is that a case of mistaken identity? Tracing Maitland in genealogical sources is a challenge. This poster identifies some of the material which has given tantalising glimpses of his life, including memorial inscriptions, obituaries, bonds and Kirk Session records. 